\title{
Efektifitas Bahan Mikro Organisme Lokal (MOL) Terhadap Pertumbuhan dan Hasil Bawang Merah (Allium Ascalonikum L.)
}

Adrianus Antoin Kunja ${ }^{a}$,

${ }^{a}$ Fakultas Pertanian, Universitas Timor, Kefamenanu, TTU-NTT, Indonesia, email:adrianuskunja2019@gmail.com

\section{Article Info}

\section{Article history:}

Received 01 Januari 2020 Accepted 21 April 2020

DOI:

https://doi.org/10.32938/sc.v5i02.945

\section{Keywords:}

Allium ascalonikum $\mathrm{L}$.

Frekuensi penyiraman
Received in revised form 22 Maret 2020

Bahan Microorganisme lokal

\begin{abstract}
Abstrak
Kebutuhan bawang merah oleh masyarakat dari tahun-ketahun mengalami peningkatan tetapi produktifitas menurun. Dengan demikian produktivitas bawang merah dalam negeri khususnya kabupaten TTU perlu ditingkatkan. Peningkatan produktivitas bawang merah perlu penyerapan teknologi yang tepat. Tujuan penelitian yakni untuk mengetahui jenis bahan mikro organisme lokal dan frekuensi penyiraman yang tepat terhadap pertumbuhan dan hasil bawang merah serta untuk mengetahui kejadian dan keparahan penyakit. Penelitan ini menggunakan Rancangan Acak Kelompok (RAK) faktorial, dengan tiga ulangan. Faktor pertama adalah jenis mol yang terdiri dari tiga aras yaitu: kontrol, mol akar bambu, mol bonggol pisang dan faktor ke dua adalah frekuensi penyiraman yaitu: satu minggu sekali, dua minggu sekali dan tiga minggu sekali. Hasil penelitian menunjukkan bahwa terjadi interaksi antara perlakuan jenis microorganism lokal dengan frekoensi penyiraman MOL terhadap parameter pengamatan berat kering per petak dan keparahan penyakit sedangkan parameter pengamatan lainnya tidak terjadi interaksi. Bahan mikroorganisme lokal yang dapat meningkatkan pertumbuhan dan hasil tanaman bawang merah adalah mikroorganisme lokal (MOL) bonggol pisang dengan frekuensi yang tepat untuk aplikasi MOL bonggol pisang adalah 3 minggu sekali. Tanaman bawang merah yang diaplikasikan dengan bahan MOL mampu menekan kejadian maupun keparahan penyakit dibandingkan dengan kontrol.
\end{abstract}

\section{Pendahuluan}

Bawang merah (Allium ascalonium L.) merupakan komoditas hortikultura yang banyak terdapat di Indonesia yang memiliki banyak manfaat. Bawang merah termasuk kelompok rempah-rempah yang tidak bersubtitusi yang berfungsi sebagai bumbu penyedap makanan dan juga sebagai bahan obatobatan. Berdasarkan data dari the national nutrient data base bawang merah mengandung: karbohidrat, gula, asam lemak, protein dan mineral lainnya yang di butuhkan oleh tubuh manusia (Waluyo \&Sinaga 2015). Bawang merah mengandung nutrisi yang cukup tinggi di mana $100 \mathrm{~g}$ umbi mengandung 9,2\% karbohidrat, $0,3 \%$ lemak, $1,5 \%$ protein, mineral, kalium (K), $334 \mathrm{mg}$ kalori (energi), $50 \mathrm{IU} ß$ karoten, $0,8 \mathrm{mg}$ zat besi, $30 \mathrm{mg}$ thiamin, $0,04 \mathrm{mg}$ riboflavin, $40 \mathrm{mg}$ fosfor dan 80-85 \% kadar air,(Adrianto, dkk 2014). Dilihat dari kandungan dan manfaat bawang merah maka kebutuhan akan bawang merah dari tahun ketahun mengalami peningkatan sebesar $5 \%$ hal tersebut di buktikan dengan adanya jumlah penduduk yang dari tahun ke tahun mengalami peningkatan. Provinsi Nusa Tenggara Timur (NTT) khususnya Kabupaten Timor Tengah Utara (TTU), menurut data BPS (2019) bahwa produksi bawang merah mengalami fluktuasi selama periode 2016-2019 dengan hasil produksi berturut-turut sebagai berikut $56,6 \mathrm{t}, 80,4 \mathrm{t}, 65,4 \mathrm{t}$, dan 24,4 t. Hal ini menunjukan bahwa produksi bawang merah di TTU mengalami penurunan yang sangat signifikan. Dilihat dari trend data yang ada bahwa terdapat masalah yang harus diselesaikan.

Masalah-masalah yang teridentifikasi adalah penggunaan pupuk kimia oleh petani yang terjadi secara terus-menerus dan berlebihan menyebabkan rusaknya lingkungan tumbuh bagi bawang merah, adanya serangan hama dan penyakit tanaman serta kurangnya tehnologi ditingkat petani. Peningkatan produktivitas bawang merah dapat dilakukan dengan penerapan teknologi yang tepat baik dari penanaman, pemeliharaan, dan panen dengan tepat dan ramah lingkungan. Teknologi yang ramah lingkungan yaitu dengan memanfaatkan bahan organik sebagai aktifator penyubur tanaman sekaligus sebagai pengendali hama peyakit oleh karena itu salah satu teknologi yang dianjurkan adalah dengan memanfaatkan mikroorganisme yang terdapat di lingkungan sekitar seperti pemanfaatan bahan mikroorganisme lokal (MOL). Mikroorganisme lokal (MOL) adalah larutan hasil fermentasi yang berbahan dasar dari berbagai sumber daya yang tersedia di alam sekitar. Larutan mol mengandung unsur hara mikro dan makro dan juga mengandung bakteri yang berpotensi sebagai perombak bahan organik, perangsang tumbuhan dan sebagai agen pengendali hama dan peyakit tanaman, Sehinga larutan mol dapat di gunakan baik secara dekomposer pupuk hayati dan sebagai pestisida organik terutama sebagai fungisida (Purwasasmita, 2009).

Mikroorganisme lokal yang banyak tersedia disekitar lingkungan berupa akar bambu dan bonggol. Menurut Nurmalasari \& Suhaeni (2019) bahwa pada perakaran bambu terdapat PGPR atau bakteri yang terdapat pada rizhosfer yaitu daerah perakaran. Mikroorganisme rhizoper atau rhizo bakteri dapat menyelubungi permukaan akar sehingga akar dapat menyerap nutrisi. Selanjutnya dikatakan bahwa bambu memiliki ketahanan terhadap cuaca ekstrim, penebangan, pembakaran serta kesuburan bambu serta dapat bertahan bahkan tumbuh subur tanpa dipupuk. Penelitian Walida et al., (2019) menunjukkan bahwa MOL rebung bambu yang telah difermentasikan untuk digunakan sebagai POC yaitu didapatkan 8 isolat bakteri dengan karakteristik makroskopis dan mikroskopis yang berbeda dan seluruh isolat bakteri yang didapat tersebut berpotensi menghambat pertumbuhan koloni jamur fusarium. Hasil penelitian Yeremia (2016) bahwa pemberian larutan MOL rebung bambu berpengaruh secara signifikan terhadap tanaman caisim dengan konsentrasi terbaik $5 \%$. Selain MOL dari bambu, bahan baku yang banyak tersedia dilingkungan dan memiliki potensi mol adalah bongkol batang pisang. Suhastyo et.al (2013) bahwa pada MOL bonggol pisang teridentifikasi Bacillus sp., Aeromonas sp. dan Aspergillus niger. Selain mengandung bakteri, MOL

bonggol pisang juga mengandung zat pengatur tumbuh seperti giberelin dan sitokinin yang dapat membantu pembelahan sel tanaman, mikroba pelarut phospat, mikroba pengurai selulosa, dan mudah didapatkan dengan biaya murah (Parlinah \& Hidayat, 2016). Perbaikan sifat tanah optimal terjadi pada frekuensi pemberian MOL bonggol pisang sebanyak 2 kali (Fauziyah, 2020). Berdasarkan uraian diatas maka penelitian ini bertujuan untuk mengetahui jenis bahan mikro organisme lokal dan frekuensi penyiraman yang tepat terhadap pertumbuhan dan hasil bawang merah serta untuk mengetahui kejadian dan keparahan penyakit.

\section{Metode}

Penelitian lapangan dilaksanakan di Desa Noebaun, Kecamatan Noemuti, Kabupaten Timor Tengah Utara (TTU), bulan Juli 2019-September 2019. Penelitian lapangan menggunakan Rancangan Acak Kelompok (RAK) faktorial. Perlakuan yang diteliti terdiri dari $3 \times 3$ diulang sebanyak 3 kali. Faktor pertama adalah jenis mol (M) yang terdiri dari tiga aras yaitu: kontrol (M0), mol akar bambu (M1), mol bongkol pisang (M2) dan faktor kedua adalah frekuensi penyiraman (F) yaitu: satu minggu sekali (F1) dua minggu sekali (F2) dan tiga minggu sekali (F3). Kombinasi M0F1,M0F2,M0F3, M1F1, M1F2, M1F3 dan M2F1, M2F2, M2F3. Sehingga keseluruhan kombinasi perlakuannya ada 27 satuan percobaan (petak). Penelitian di awali dengan: persiapan lahan, pemilihan bibit, pembuatan mol, perlakuan benih, penanaman, pemeliharaan meliputi penyulaman, penyiangan, pemupukan dengan mengaplikasikan mol dan panen. Parameter pertumbuhan, hasil dan kejadian dan keparahan penyakit meliputi: tinggi tanaman, jumlah daun, berat segar umbi per sampel, berat segar umbi per petak, berat kering umbi per sampel, berat kering umbi per petak, berat berangkasan per petak, indeks panen, kejadian peyakit dan keparahan penyakit. Data hasil pengamatan dianalisa dengan menggunakan sidik ragam anova Rancangan Acak Kelompok (RAK) untuk mengetahui ada tidaknya pengaruh antara faktor perlakuan. Rata-rata perlakuan selanjutnya diuji dengan Duncan Multiple Range Tes (DMRT) dengan tingkat siknifikan @ 5 \% sesuai petunjuk Gomez dan Gomez (2010), analisis data menggunakan program sas 9.1

\section{Hasil dan Pembahasan \\ 3.1 Hasil \\ Tinggi Tanaman}

Berdasarkan hasil sidik ragam anova menunjukkan bahwa pemberian mikroorganisme lokal (MOL) dan frekuensi penyiraman tidak terjadi interaksi pada parameter tinggi tanaman 21 hst, 28 hst dan 35 hst. Data parameter ini menunjukkan bahwa pemberian mikro organisme lokal (MOL) bonggol pisang memberikan pertumbuhan tertinggi dan tidak berbeda nyata dengan perlakuan lainnya (Tabel 1). Aras perlakuan frekuensi penyiraman tiga minggu sekali memberikan pertumbuhan tertinggi pada semua waktu pengamatan dan berbeda nyata dengan perlakuan lainnya pada pengamatan 21 hst dan 28 hst.

\section{Jumlah Daun}

Berdasarkan hasil sidik ragam anova menunjukkan bahwa pemberian mikro organisme lokal (MOL) dan frekuensi penyiraman tidak terjadi interaksi pada parameter jumlah daun. Parameter ini menunjukan bahwa pemberian mikro organisme lokal (MOL) bonggol pisang memberikan jumlah daun terbanyak dan berbeda nyata pada parameter pengamatan 21 hst sedangkan parameter 28 hst dan 35 hst tidak berbeda nyata (Tabel 2). Frekuensi penyiraman tiga minggu sekali memberikan jumlah daun tertinggi pada semua waktu pengamatan dan tidak berbeda nyata pada pengamatan 35 hst. 


\section{Berat Segar Per Sampel}

Berdasarkan hasil sidik ragam anova menjukkan bahwa pemberian mikro organisme lokal (MOL) dan frekuensi penyiraman tidak terjadi interaksi pada parameter berat segar per sampel. Data parameter ini menunjukan bahwa pemberian mikro organisme lokal (MOL) bonggol pisang memberikan berat segar per sampel tertingi $(35,99)$ dan berbeda nyata dengan perlakuan tanpa MOL (kontrol). Perlakuan rekuensi penyiraman tiga minggu sekali menghasilkan berat segar per sampel tertinggi $(28,36)$ dan tidak beda nyata dengan perlakuan lainnya (Tabel 3 )

Tabel 1. Tinggi Tanaman $(\mathrm{cm})$

\begin{tabular}{|c|c|c|c|c|c|}
\hline \multirow{2}{*}{$\begin{array}{c}\text { Waktu } \\
\text { Pengamatan } \\
\text { (HST) }\end{array}$} & \multirow[b]{2}{*}{ Perlakuan } & \multicolumn{3}{|c|}{ Frekuensi Penyiraman } & \multirow[b]{2}{*}{ Rerata } \\
\hline & & $\begin{array}{c}\text { Satu } \\
\text { Minggu }\end{array}$ & $\begin{array}{c}\text { Dua } \\
\text { Mingu }\end{array}$ & $\begin{array}{c}\text { Tiga } \\
\text { Minggu }\end{array}$ & \\
\hline \multirow{4}{*}{ 21HST } & Kontrol & 12,75 & 12,58 & 14,00 & $13,11^{\mathrm{a}}$ \\
\hline & Mol Akar Bambu & 12,53 & 14,67 & 14,21 & $13,80^{\mathrm{a}}$ \\
\hline & Mol Bonggol Pisang & 13,2 & 13,08 & 15,55 & $13,94^{\mathrm{a}}$ \\
\hline & Rerata & $12,82^{\mathrm{b}}$ & $13,44^{\mathrm{b}}$ & $14,58^{\mathrm{a}}$ & $(-)$ \\
\hline \multirow{4}{*}{$28 \mathrm{HST}$} & Kontrol & 14,85 & 13,87 & 15,83 & $14,85^{\mathrm{a}}$ \\
\hline & Mol Akar Bambu & 14,15 & 14,67 & 15,41 & $14,74^{\mathrm{a}}$ \\
\hline & Mol Bonggol Pisang & 14,19 & 14,67 & 19,95 & $16,16^{\mathrm{a}}$ \\
\hline & Rerata & $14,40^{\mathrm{b}}$ & $14,67^{\mathrm{b}}$ & $17,06^{\mathrm{a}}$ & $(-)$ \\
\hline \multirow{4}{*}{$35 \mathrm{HST}$} & Kontrol & 17,83 & 15,67 & 16,85 & $16,79^{\mathrm{a}}$ \\
\hline & Mol Akar Bambu & 15,65 & 16,66 & 16,2 & $16,17^{\mathrm{a}}$ \\
\hline & Mol Bonggol Pisang & 14,65 & 16,11 & 19,95 & $16,90^{\mathrm{a}}$ \\
\hline & Rerata & $16,04^{\mathrm{a}}$ & $16,15^{\mathrm{a}}$ & $17,67^{\mathrm{a}}$ & $(-)$ \\
\hline
\end{tabular}

Keterangan :Angka pada baris dan kolom diikuti huruf yang sama menunjukan tidak beda nyata pada tingkat nyata $(\alpha) 5 \%$ menurut uji DMRT. (-) tidak terjadi interaksi antar faktor.

Tabel 2. Jumlah Daun (helai)

\begin{tabular}{|c|c|c|c|c|c|}
\hline \multirow{2}{*}{$\begin{array}{c}\text { Waktu } \\
\text { Pengamatan } \\
(\text { HST })\end{array}$} & \multirow[b]{2}{*}{ Perlakuan } & \multicolumn{3}{|c|}{ Frekuensi Penyiraman } & \multirow[b]{2}{*}{ Rerata } \\
\hline & & $\begin{array}{c}\text { Satu } \\
\text { Minggu }\end{array}$ & $\begin{array}{c}\text { Dua } \\
\text { Minggu }\end{array}$ & $\begin{array}{c}\text { Tiga } \\
\text { Mingu } \\
\end{array}$ & \\
\hline \multirow{4}{*}{$21 \mathrm{HST}$} & Kontrol & 10,93 & 9,53 & 10,13 & $10,20^{\mathrm{a}}$ \\
\hline & Mol Akar Bambu & 12,2 & 10,07 & 12,4 & $11,56^{\mathrm{a}}$ \\
\hline & Mol Bonggol Pisang & 11,13 & 13,07 & 14,4 & $12,87^{\mathrm{a}}$ \\
\hline & Rerata & $11,42^{\mathrm{b}}$ & $10,89^{\mathrm{b}}$ & $12,31^{\mathrm{a}}$ & $(-)$ \\
\hline \multirow{4}{*}{ 28HST } & Kontrol & 13,13 & 12 & 15,58 & $13,57^{\mathrm{a}}$ \\
\hline & Mol Akar Bambu & 15,53 & 13,73 & 16,13 & $15,13^{\mathrm{a}}$ \\
\hline & Mol Bonggol Pisang & 14,07 & 14,4 & 19,6 & $16,02^{\mathrm{a}}$ \\
\hline & Rerata & $14,24^{\mathrm{b}}$ & $13,38^{\mathrm{b}}$ & $17,10^{\mathrm{a}}$ & $(-)$ \\
\hline \multirow{4}{*}{35 HST } & Kontrol & 17,33 & 14,87 & 17,4 & $16,53^{\mathrm{a}}$ \\
\hline & Mol Akar Bambu & 18,73 & 16,6 & 17,4 & $17,58^{\mathrm{a}}$ \\
\hline & Mol Bonggol Pisang & 16,47 & 17,07 & 23,4 & $18,98^{\mathrm{a}}$ \\
\hline & Rerata & $17,51^{\mathrm{a}}$ & $16,18^{\mathrm{a}}$ & $19,4^{\mathrm{a}}$ & $(-)$ \\
\hline
\end{tabular}

$\overline{\text { Keterangan :Angka pada baris dan kolom diikuti huruf yang sama menunjukan tidak beda }}$ nyata pada tingkat nyata $(\alpha) 5 \%$ menurut uji DMRT. (-) tidak terjadi interaksi antar faktor.

Tabel 3. Berat Segar Per Sampel (g).

\begin{tabular}{lcccc}
\hline \multirow{2}{*}{ Perlakuan } & \multicolumn{3}{c}{ Frekuensi Penyiraman } & \multirow{2}{*}{ Rerata } \\
\cline { 2 - 4 } & Satu Minggu & Dua Minggu & Tiga Minggu & \\
\hline Kontrol & 18,03 & 13,40 & 13,12 & $14,85^{\mathrm{b}}$ \\
Mol Akar Bambu & 32,63 & 28,97 & 34,54 & $32,05^{\mathrm{a}}$ \\
Mol Bonggol Pisang & 28,72 & 41,83 & 37,42 & $35,99^{\mathrm{a}}$ \\
\hline Rerata & $26,46^{\mathrm{a}}$ & $28,07^{\mathrm{a}}$ & $28,36^{\mathrm{a}}$ & $(-)$ \\
\hline Kenynn
\end{tabular}

Keterangan:Angka pada baris dan kolom diikuti huruf yang sama menunjukan berbeda tidak nyata pada tingkat nyata $(\alpha) 5 \%$ menurut uji DMRT. (-) tidak terjadi interaksi antar faktor

\section{Berat Segar Per Petak}

Berdasarkan hasil sidik ragam anova menunjukkan bahwa pemberian mikro organisme lokal (MOL) dan frekuensi penyiraman tidak terjadi interaksi pada parameter berat segar per petak. Data parameter ini menunjukan bahwa pemberian mikro organisme lokal (MOL) bonggol pisang memberikan berat segar per petak tertingi $(667,84)$ dan berbeda nyata dengan perlakuan tanpa MOL (kontrol). Perlakuan frekuensi penyiraman dua minggu sekali menghasilkan berat segar per petak tertinggi $(564,20)$ dan tidak beda nyata dengan perlakuan lainnya (Tabel 4)

Tabel 4. Berat Segar Per Petak (g)

\begin{tabular}{lcccc}
\hline \multirow{2}{*}{ Perlakuan } & \multicolumn{3}{c}{ Frekuensi Penyiraman } & \multirow{2}{*}{ Rerata } \\
\cline { 2 - 4 } & Satu Minggu & Dua Minggu & Tiga Minggu & \\
\hline Kontrol & 323,30 & 275,23 & 212,82 & $270,45^{\text {b }}$ \\
Mol Akar Bambu & 626,70 & 643,56 & 693,28 & $654,51^{\text {a }}$ \\
Mol Bonggol Pisang & 604,50 & 773,82 & 625,20 & $667,84^{\text {a }}$ \\
\hline Rerata & $518,17^{\text {a }}$ & $564,20^{\text {a }}$ & $510,43^{\text {a }}$ & $(-)$ \\
\hline
\end{tabular}

Keterangan :Angka pada baris dan kolom diikuti huruf yang sama menunjukan berbeda tidak nyata pada tingkat nyata $(\alpha) 5 \%$ menurut uji DMRT. (-) tidak terjadi interaksi antar faktor

\section{Berat Kering Per Sampel}

Berdasarkan hasil sidik ragam anova menunjukkan bahwa pemberian mikro organisme lokal (MOL) dan frekuensi penyiraman tidak terjadi interaksi pada parameter berat kering per sampel. Data parameter ini menunjukkan bahwa pemberian mikro organisme lokal (MOL) bonggol pisang memberikan berat kering per sampel tertingi $(23,95)$ dan berbeda nyata dengan perlakuan tanpa MOL (kontrol). Perlakuan frekuensi penyiraman satu minggu sekali menghasilkan berat kering per sampel tertinggi $(20,73)$ dan tidak berbeda nyata dengan perlakuan lainnya (Tabel 5)

Tabel 5. Berat Kering Per Sampel (g)

\begin{tabular}{lcccc}
\hline \multirow{2}{*}{ Perlakuan } & \multicolumn{3}{c}{ Frekuensi Penyiraman } & \multirow{2}{*}{ Rerata } \\
\cline { 2 - 5 } & Satu Minggu & Dua Minggu & Tiga Minggu & \\
\hline Kontrol & 13,73 & 12,49 & 10,33 & $12,18^{\mathrm{b}}$ \\
Mol Akat Bambu & 21,81 & 20,54 & 21,72 & $21,36^{\mathrm{a}}$ \\
Mol Bonggol Pisang & 26,66 & 21,03 & 24,16 & $23,95^{\mathrm{a}}$ \\
\hline Rerata & $20,73^{\mathrm{a}}$ & $18,02^{\mathrm{a}}$ & $18,74^{\mathrm{a}}$ & $(-)$ \\
\hline
\end{tabular}

Keterangan :Angka pada baris dan kolom diikuti huruf yang sama menunjukan berbeda tidak nyata pada tingkat nyata $(\alpha) 5 \%$ menurut uji DMRT. (-) tidak terjadi interaksi antar faktor.

\section{Berat Kering Per Petak}

Berdasarkan hasil sidik ragam anova menunjukkan bahwa pemberian mikro organisme lokal (MOL) dan frekuensi penyiraman terjadi interaksi pada parameter berat kering per petak. Data parameter ini menunjukkan bahwa pemberian mikro organisme lokal (MOL) bonggol pisang memberikan hasil terbaik pada frekuensi tiga minggu sekali $(418,72)$ dan berbeda nyata dengan tanpa pemnberian MOL (kontrol) tetapi tidak berbeda nyata dengan perlakuan lainnya (Tabel 6)

\section{Tabel 6. Berat Kering Per Petak (g)}

\begin{tabular}{lcccc}
\hline \multirow{2}{*}{ Perlakuan } & \multicolumn{3}{c}{ Frekunsi Penyiraman } & \multirow{2}{*}{ Rerata } \\
\cline { 2 - 4 } & Satu Minggu & Dua Minggu & Tiga Minggu & \\
\hline Kontrol & $216,82 \mathrm{~b}$ & $167,81 \mathrm{~b}$ & $144,88 \mathrm{~b}$ & 176,50 \\
Mol Akar Bambu & $382,54 \mathrm{ab}$ & $378,49 \mathrm{ab}$ & $395,25 \mathrm{ab}$ & 385,43 \\
Mol Bonggol Pisang & $417,56 \mathrm{a}$ & $348,33 \mathrm{ab}$ & $418,72 \mathrm{a}$ & 394,87 \\
\hline Rerata & 338,97 & 298,21 & 319,62 & $(+)$ \\
\hline
\end{tabular}

Keterangan:Angka pada baris dan kolom diikuti huruf yang sama menunjukan berbeda tidak nyata pada tingkat nyata $(\alpha) 5 \%$ menurut uji DMRT. (+) t terjadi interaksi antar faktor.

\section{Berat Berangkasan}

Berdasarkan hasil sidik ragam anova menunjukkan bahwa pemberian mikro organisme lokal (MOL) dan frekuensi penyiraman tidak terjadi interaksi pada parameter berat berangkasan. Data penelitian ini menunjukan bahwa pemberian mikro organisme lokal (MOL) akar bambu memberikan berat berangkasan tertingi $(351,12)$ dan berbeda nyatadengan perlakuan tanpa MOL (kontrol). Frekuensi penyiraman tiga minggu sekali menghasilkan berat berangkasan tertinggi $(275,89)$ dan tidak beda nyata dengan perlakuan lainnya (Tabel 7).

Tabel 7. Berat Berangkasan (g)

\begin{tabular}{lcccc}
\hline \multirow{2}{*}{ Perlakuan } & \multicolumn{3}{c}{ Frekunsi Penyiraman } & \multirow{2}{*}{ Rerata } \\
\cline { 2 - 5 } & Satu minggu & Dua minggu & Tiga Minggu & \\
\hline Kontrol & 131,70 & 149,79 & 116,45 & $132,65^{\mathrm{b}}$ \\
Mol Akar Bambu & 347,17 & 367,51 & 338,69 & $351,12^{\mathrm{a}}$ \\
Mol Bonggol Pisang & 289,88 & 271,99 & 372,52 & $311,46^{\mathrm{a}}$ \\
\hline Rerata & $256,25^{\mathrm{a}}$ & $263,10^{\mathrm{a}}$ & $275,89^{\mathrm{a}}$ & $(-)$ \\
\hline
\end{tabular}

Keterangan :Angka pada baris dan kolom diikuti huruf yang sama menunjukan berbeda tidak nyata pada tingkat nyata( $\alpha) 5 \%$ menurut uji DMRT. (-) tidak terjadi interaksi antar faktor

\section{Indeks Panen}

Berdasarkan hasil sidik ragam anova menjukkan bahwa pemberian mikro organisme lokal (MOL) dan frekuensi penyiraman tidak terjadi interaksi pada parameter indeks panen. Data parameter ini menunjukan bahwa pemberian mikro organisme lokal (MOL) bonggol pisang memberikan indeks panen tertingi $(1,56)$ dan perlakuan frekuensi penyiraman satu minggu sekali menghasilkan indeks panen tertinggi $(1,66)$ dan tidak berbeda nyata dengan perlakuan lainnya (Tabel 8).

Tabel 8. Indeks panen $(\%)$

\begin{tabular}{lcccc}
\hline \multirow{2}{*}{ Perlakuan } & \multicolumn{3}{c}{ Frekunsi Penyiraman } & \multirow{2}{*}{ Rerata } \\
\cline { 2 - 4 } Kontrol & Satu Mingu & Dua Minggu & Tiga Minggu & \\
Mol Akar Bambu & 1,69 & 1,13 & 1,23 & $1,35^{\mathrm{a}}$ \\
Mol Bonggol Pisang & 1,12 & 1,11 & 1,18 & $1,14^{\mathrm{a}}$ \\
\hline Rerata & 2,16 & 1,36 & 1,15 & $1,56^{\mathrm{a}}$ \\
\hline
\end{tabular}

Keterangan :Angka pada baris dan kolom diikuti huruf yang sama menunjukan berbeda tidak nyata pada tingkat nyata( $\alpha$ ) $5 \%$ menurut uji DMRT. (-) tidak terjadi interaksi antar faktor 


\section{Kejadian Penyakit}

Berdasarkan hasil sidik ragam anova menunjukkan bahwa pemberian mikro organisme lokal (MOL) dan frekuensi penyiraman tidak terjadi interaksi pada parameter kejadian penyakit. Data parameter ini menunjukan pada perlakuan mol akar bambu menunjukan kejadian penyakit terendah $(0,7)$ dan Perlakuan frekuensi penyiraman dua minggu sekali menghasilkan kejadian penyakit terendah $(0,10)$ dan tidak berbeda nyata dengan perlakuan lainnya (Tabel 9).

\section{Tabel 9. Kejadian Penyakit}

\begin{tabular}{lcccc}
\hline \multirow{2}{*}{ Perlakuan } & \multicolumn{3}{c}{ Frekunsi Penyiraman } & \multirow{2}{*}{ Rerata } \\
\cline { 2 - 4 } & Satu Minggu & Dua Minggu & Tiga Minggu & \\
\hline Kontrol & 0,09 & 0,16 & 0,25 & $0,17^{\mathrm{a}}$ \\
Mol Akar Bambu & 0,07 & 0,08 & 0,08 & $0,07^{\mathrm{a}}$ \\
Mol Bonggol Pisang & 0,16 & 0,07 & 0,11 & $0,11^{\mathrm{a}}$ \\
\hline Rerata & $0,11^{\mathrm{a}}$ & $0,10^{\mathrm{b}}$ & $0,14^{\mathrm{a}}$ & $(-)$ \\
\hline Keterangan
\end{tabular}

Keterangan :Angka pada baris dan kolom diikuti huruf yang sama menunjukan berbeda tidak nyata pada tingkat nyata $(\alpha) 5 \%$ menurut uji DMRT. (-) terjadi interaksi antar faktor

\section{Keparahan Penyakit}

Berdasarkan hasil sidik ragam anova menjukkan bahwa pemberian mikro organisme lokal (MOL) dan frekuensi penyiraman terjadi interaksi pada parameter keparahan penyakit. Data parameter ini menunjukan bahwa pada perlakuan mol akar bambu pada frekuensi satu minggu sekali menunjukan hasil terbaik pada keparahan penyakit dan mol bonggol pisang pada frekuensi dua minggu sekali menunjukan hasil terbaik pada keparahan penyakit $(0,33)$ dan berbeda nyata dengan perlakuan tanpa mol (kontrol) pada frekuensi tiga minggu sekali namun tidak berbeda nyata dengan perlakuan lainnya (Tabel $10)$.

\section{Tabel 10. Keparahan Penyakit (\%)}

\begin{tabular}{lcccc}
\hline \multirow{2}{*}{ Perlakuan } & \multicolumn{3}{c}{ Frekunsi Penyiraman } & \multirow{2}{*}{ Rerata } \\
\cline { 2 - 4 } & Satu minggu & Dua minggu & Tiga minggu & \\
\hline Kontrol & $0,47^{\mathrm{b}}$ & $7,13^{\mathrm{b}}$ & $25,33^{\mathrm{a}}$ & 10,98 \\
Mol akar bambu & $0,33^{\mathrm{b}}$ & $0,40^{\mathrm{b}}$ & $0,34^{\mathrm{b}}$ & 0,36 \\
Mol bonggol pisang & $7,13^{\mathrm{b}}$ & $0,33^{\mathrm{b}}$ & $0,53^{\mathrm{b}}$ & 2,67 \\
\hline Rerata & 2,99 & 3,01 & 11,07 & $(+)$ \\
\hline
\end{tabular}

Keterangan :Angka pada baris dan kolom diikuti huruf yang sama menunjukan berbeda tidak nyata pada tingkat nyata $(\alpha) 5 \%$ menurut uji DMRT. (+) terjadi interaksi antar faktor

\subsection{Pembahasan}

Hasil penelitian menunjukan mikro organisme lokal bonggol pisang dan frekuensi tiga minggu sekali $\left(\mathrm{M}_{2} \mathrm{~F}_{3}\right)$ menunjukan hasil tertinggi pada tinggi tanaman 21 hst, 28 hst dan 35 hst dan jumlah daun 21 hst, 28 hst dan 35 hst. Pada frekuensi tiga minggu sekali bahan mikroorganisme lokal bonggol pisang dapat diserap oleh tanaman dengan baik sehingga memacu pertumbuhan tanaman. Hal ini sesuai dengan pernyataan Sutedjo \& Kartasapoetra (1988) menyebutkan bahwa waktu aplikasi menentukan pertumbuhan tanaman. Berbedanya waktu aplikasi akan memberikan hasil yang tidak sesuai dengan pertumbuhan tanaman. Pemberian pupuk dengan interval waktu yang terlalu sering dapat menyebabkan konsumsi mewah, sehingga menyebabkan pemborosan pupuk sebaliknya bila interval pemupukan terlalu jarang dapat menyebabkan kebutuhan hara tanaman kurang terpenuhi. Hasil penelitian menunjukkan berat segar per sampel tertigi yaitu pada perlakuan bahan mikroorganisme lokal (MOL) bonggol pisang pada frekuensi penyiraman tiga minggu sekali, sedangkan per petak yang menunjukan berat ter tinggi adalah pada perlakuan bahan mikro organisme lokal (MOL) bonggol pisang pada frekuensi penyiraman dua minggu sekali, berat kering per sampel dan petak yang menunjukan berat tertinggi yaitu bahan mikro organisme lokal (MOL) bonggol pisang pada frekuensi penyiraman satu minggu sekali, berat berangkasan yang menunjukan hasi tertingi yaitu bahan mikroorganisme lokal (MOL) bonggol pisang pada frekuensi penyiraman tiga minggu sekali, sedangkan indeks panen yang menunjukan hasil tertinggi yaitu bahan mikroorganisme lokal (MOL) bonggol pisang pada frekuensi penyiraman satu minggu sekali.

Perbedaan berat pada berat kering, berat berangkasan dan indeks panen di sebabkan pada saat penggeringan kandungan air yang ada pada perlakuan lain lebih tinggi di bandingkan zat hara yang terkandung sehingga pada saat pengeringan kandungan air hilang melalui proses penguapan hal ini di dukung oleh Lestari (2008) yang memaparkan bahwa hasil berat kering merupakan keseimbangan antara fotosintesis dan respirasi. Fotosintesis dan respirasi yang maksimal akan meningkatkan berat kering tanaman. Proses ini akan berjalan dengan optimal bila tanaman mendapatkan hara dan unsur penting yang lain dalam jumah yang optimal juga. Jika kekurangan hara, tanaman tidak akan dapat berfotosintesis secara maksimal.

Hasil penelitian menunjukkan pada parameter kejadian penyakit yang terbaik yaitu mikro roganisme lokal (MOL) akar bambu pada frekuensi dua minggu sekali (M1F2) sedangkan parameter keparahan penyakit yang terbaik yaitu mol akar bambu pada frekuensi satu minggu sekali (M1F1), karena MOL akar bamu pada frekuensi dua minggu sekali dan satu minggu sekali dapat menekan pertumbuhan patogen hal ini didukung literatur (Tenuta,2006; Cattelan,1993) yang menyatakan PGPR akar bambu sebagai pengendali patogen yang berasal dari tanah (bioprotectanas) dengan cara menghasilkan berbagai senyawa atau metabolit anti patogen. Dan MOL bonggol pisang pada frekuensi dua minggu sekali (M2F2) hal ini karena MOL bonggol pisang pada frekuensi dua minggu sekali dapat merangsang tanaman sehinga tanaman toleran terhadap hama dan penyakit hal ini di dukung oleh Setianingsih (2009) menyatakan MOL bonggol pisang memiliki peranan dalam masa pertumbuhan vegetatif tanaman dan tanaman toleran terhadap penyakit.

\section{Simpulan}

Berdasarkan penelitian yang telah dilaksanakan, maka dapat disimpulkan bahwa terjadi interaksi antara perlakuan jenis mikroorganisme lokal dengan frekuensi penyiraman MOL terhadap parameter pengamatan berat kering per petak dan keparahan penyakit sedangkan parameter pengamatan lainnya tidak terjadi interaksi. Bahan mikroorganisme lokal yang dapat meningkatkan pertumbuhan dan hasil tanaman bawang merah adalah mikroorganisme lokal (MOL) bonggol pisang dengan frekuensi yang tepat untuk aplikasi MOL bonggol pisang adalah 3 minggu sekali. Tanaman bawang merah yang diaplikasikan dengan bahan MOL mampu menekan kejadian maupun keparahan penyakit dibandingkan dengan kontrol.

\section{Pustaka}

Adrianto, Tahana Taufiq. 2014. Pengantar Ilmu Pertanian. Yogyakarta : Global Pustaka Utama

BPS (2019) Statistik Pertanian, Badan Pusat Statistik Kabupaten Timor Tengah Utara

Fauziyah Nadhifa Hasna, Susilo Budiyanto dan Adriani Darmawati Sudarman. 2020. Pengaruh Pupuk Kompos dan Frekuensi Pemberian Mol Bonggol Pisang Terhadap Pertumbuhan Dan Produktivitas Stroberi (Fragaria sp.)

Gomez K A dan Gomez A A. 1995. Prosedur Statistik Untuk Penelitian Pertanian. Edisi ke 2. UI Press: Jakarta

Lestari, G.M, Solichatun, dan Sugiyarto. 2008. Pertumbuhan, Kandungan Klorofil, dan Laju Respirasi Tanaman Garut (Maranta arundinacea L) Setelah pemberian Asam Giberelat (GA3) Jurnal Bioteknologi. Vol. X (1) : 1-9. UNS Press. Surakarta.

Nurmala sari dan Suhaeni, (2019), Pendampingan Pembuatan Mikro Organisme Lokal (MOL) Bagi Masyarakat Desa Salu Induk. Laporan pengabdian pada masyarakat Universitas Cokro Aminoto Palopo.

Purwasasmita M, Kunia K. 2009. Mikroorganisme lokal sebagai pemicu siklus kehidupan dalam biorektor tanaman. Seminar nasional teknik kimia Indonesia, 19-20 Oktober 2019

Parlinah, L., dan O. Hidayat. 2016. Mikroorganisme Lokal dalam pengomposan pada mutu lobak var greenbow yang dipanen berbeda. Paspalum 4 (1) : $40-48$

Sutedjo, Mulyani Mul Dan A.G Karta Sapoetra.1988. Pengantar Ilmu Tanah Jakarta:PT. Bina Aksara

Suhastyo Arum Asriyanti, Iswandi Anas, Dwi Andreas Santosa, Yulin Lestari. 2013. Studi Mikrobiologi Dan Sifat Kimia Mikroorganisme Lokal (MOL) Yang Digunakan Pada Budidaya Padi Metode Sri (System of Rice Intensification).Jurnal Sainteks Volume X No. 2

Setianingsih R. 2009. Kajian pemanfaatan pupuk organik cair mikroorganisme lokal (MOL) dalam priming. umur bibit dan peningkatan daya hasil tanaman padi (Oryza sativa L.) (uji coba penerapan System of Rice Intensification (SRI)) [Tesis]. Surakarta: Fakultas Pertanian Universitas Sebelas Maret.

CattelanM. 2006 M.2006 Plat Growth Promiting Rhizobacteria:Prospect For Increasing Nutriant Acquisition And Disese Control.

Waluyo ,N., sinaga R. Bawang merah yang dirilis oleh balai pertanian tanaman sayuran. Iptek Tanaman Sayuran. Balai penelitian tanaman sayuran , Lembang.

Walida Hilwa, Agung Permadi, Fitra Syawal Harahap dan Badrul Ainy Dalimunthe. 2019. Isolasi Dan Uji Antagonis Mikroorganisme Lokal (Mol) Rebung Bambu Terhadap Cendawan Fusarium sp., Jurnal Agroplasma, Vol 6 No 2 